\title{
Effects of water and nutrient addition on the coppice growth response of cut Terminalia sericea
}

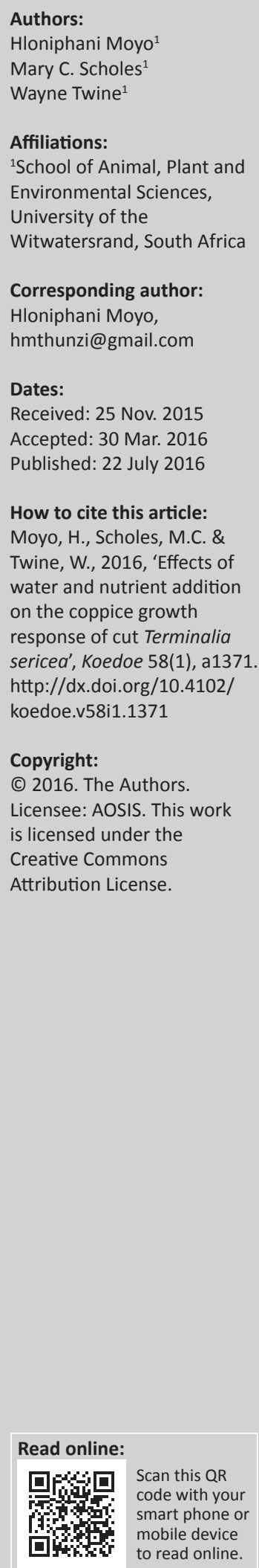

The ability of a woody plant to coppice and remain vigorous largely depends on the severity of disturbances, resource availability and the mobilisation of stored reserves. There is limited information about the role played by resource limitation on the recovery of cut trees. This study investigated the effects of water and nutrient supplementation on coppice growth responses of resprouting cut trees in a semi-arid savannah in South Africa. Cut trees were exposed to different levels of water and nutrient (nitrogen and phosphorus) supplementation over a period of 2 years in a factorial experimental design. We hypothesised that adding water and nutrients would result in an increased coppice growth response and replenishment of stored structural reserves. Adding water and nutrients significantly increased shoot diameter, shoot length and resprouting ratio for the initial 12 months after cutting but not stored structural reserves. Such a response pattern suggests that the initial growth of resprouting shoots may be strongly resource-limited, while resources are concentrated on supporting fewer resprouting shoots compared to a higher number.

Conservation implications: If practicing rotational tree harvesting, trees resprouting in resource-poor locations need a longer resting period to recover stored reserves and to also recover lost height after cutting.

\section{Introduction}

Plants are subjected to various forms of disturbances and stresses that affect their growth, production and survival. When recovering lost biomass after a disturbance, resource availability and exposure to further disturbances limit the full recovery of plants growing in a disturbed ecosystem (Hoffmann, Schroeder \& Jackson 2002; Holdo, Holt \& Fryxell 2009). Thus, there is a need to understand the importance of tree resource use as well as the factors that affect tree recovery as influenced by climatic factors. An understanding of how disturbances and resource availability interact will have further management implications for the long-term productivity and sustainability of woody vegetation (Neke 2004; Neke, Owen-Smith \& Witkowski 2006; Pote et al. 2006). As a result of exposure to disturbances, coppicing (resprouting) may be central to the survival and resilience of trees in disturbance-prone systems (Avohou et al. 2011). Coppicing can be defined as the production of vegetative shoots at the base of the stem or sprouts arising from a stump, resulting in the emergence of new shoots from the stump or roots (Hardesty 1984; Laureysens et al. 2003; Van Wyk \& Van Wyk 1997).

Following a disturbance event, an increase in nutrient and water availability stimulates growth rates and allocation to storage in resprouting organs (Cruz et al. 2002; Sankaran, Ratnam \& Hanan 2008). This is supported by the study of Cruz et al. (2002), who suggest that resprout growth is limited by the low amount of moisture during the early stages of regeneration. In other instances, an increase in water and nutrient availability after a disturbance may increase woody plant vegetation, leading to bush encroachment and therefore reducing biodiversity and the overall productivity of the ecosystem (Ward 2005). For example, water availability was shown to be positively correlated with regeneration in Acacia tortilis (Forssk) in Tunisia (Noumi et al. 2010) and in Populus tristis Fisch and Populus balsamifera in the USA (Dickmann, Nguyen \& Pregitzer 1996).

Nutrients play a key role in replenishing depleted stored nutrient reserves of plants after a disturbance such as tree cutting (Bowen \& Pate 1992) and their interaction with moisture affects coppice regrowth (Castell \& Terradas 1994). Because nitrogen $(\mathrm{N})$ in the remaining plant parts is used for reconstructing new tissue, adding more $\mathrm{N}$ increases root $\mathrm{N}$ storage for later use after a disturbance (El Omari et al. 2003; Kabeya \& Sakai 2005). More N also increases concentrations of photosynthetic enzymes, which in turn cause a higher rate of photosynthesis in leaves (Chapin III 
1991). In fertilised resprouting Erica australis L. Com., trees grew faster and produced higher biomass than un-fertilised trees 2 years after fertiliser application in Spain (Cruz et al. 2002). Nutrient addition also increased both diameter and height of Betula pendula Roth. and willow (Salix spp.) stands in Finland (Hytonen \& Kaunisto 1999).

It has been suggested that stored carbohydrate reserves and surviving meristems are the most important resources controlling resprouting after disturbances, with differences in soil nutrient levels also affecting stored carbohydrate reserves (Bellingham \& Sparrow 2000; Bond \& Midgley 2001; Kabeya \& Sakai 2005). For example, carbohydrate reserve concentration in resprouting Quercus crispula Blume was positively correlated to resprouting shoot length and leaf number (Kabeya et al. 2003), while starch concentrations in roots of coppicing Salix viminalis L., were higher in trees that received higher levels of $\mathrm{N}$ compared to plants that received lower levels (Fircks \& SennerbyForsse 1998).

Surprisingly, little is known about the regeneration strategies of woody species in tropical and subtropical savannahs (Neke 2004; Pote et al. 2006). This is because most studies have focused on ecosystems that differ markedly from African woodlands, such as temperate ecosystems (Wilson 2002). Such ecosystems differ in terms of the seasonality and distribution of rainfall, tree population structure, moisture levels and tree densities. Most studies on tree responses have also strongly focused on the effects of varying resource levels on seedling growth and survival (Cheng \& Fuchigami 2002; Druege et al. 2000; Kraaij \& Ward 2006; Scogings \& Mopipi 2008; Wendler \& Millard 1996; Wilson \& Witkowski 1998), rather than mature and established trees. Knowing such information will provide clues for understanding mechanisms underlying a tree's regrowth strategies after a disturbance. Also, such information would assist in evaluating how changes in resource availability may impact a community exposed to different disturbance types and frequencies.

This study was carried out to investigate how the addition of water and nutrients interact to influence tree regrowth (in terms of shoot production, shoot length and diameter, and resprout ratio) as well as the total non-structural carbohydrate (TNC) storage capacity after cutting. The following question was asked: how do varying levels of water and nutrient supplementation influence the coppice response and stem TNC reserves of cut trees? It was hypothesised that supplementing resprouting trees with water and nutrients would increase coppice response and would also result in higher TNC levels in supplemented trees compared with unsupplemented trees.

\section{Research method and design}

The study site and the experimental design were described previously (Moyo, Scholes \& Twine 2015b); a brief description of both the site and the design follows.

\section{Setting}

The experiment was conducted at the Wits Rural Facility (WRF), a 350-ha research station in the central savannah lowveld region of Limpopo Province, South Africa (24 $30^{\prime} \mathrm{S}$; $\left.31^{\circ} 06^{\prime} \mathrm{E}\right)$. The study site is semi-arid, with a mean annual rainfall of $\sim 650 \mathrm{~mm}$, concentrated in the summer season (between October and April) (Figure 1b) (Kaschula, Twine \& Scholes 2005a; Neke et al. 2006; Shackleton 1997). The study spanned a 2-year period, starting at the end of the dry season of 2010 (September 30), during the period when trees begin leaf-flush, and ending in September 2012 (Moyo, Scholes \& Twine 2015a; Moyo et al. 2015b).

\section{Design}

A $3 \times 3$ factorial experiment (nine plots in each site) replicated in three sites, was established in September 2010 to determine the effects of water and nutrient additions on the coppice response of Terminalia sericea. All three sites were on the slope crests. Therefore, they had shallow, coarse-textured and dystrophic soils (Neke 2004; Shackleton 1997; Shackleton 1999) (Moyo et al. 2015). Plots within a site were separated by a distance of approximately $15 \mathrm{~m}$, with a density of approximately 1400 trees per ha. Ten trees were selected per plot (with a distance of about $2 \mathrm{~m}$ separating each tree from the adjacent one) with the number totalling 270 for the experiment. While root systems of $T$. sericea extend horizontally, this distance was considered adequate to avoid uptake of water and nutrients by the neighbouring trees.

Trees were cut at a standard height of approximately $25 \mathrm{~cm}$ from the ground, because research has shown that cutting height influences coppice response (Ibrahima et al. 2007; Kaschula, Twine \& Scholes 2005b; Khan \& Tripathi 1986; Shackleton 1997) (Moyo et al. 2015b). A 30-cm radius was marked around each tree, and grass was cleared to reduce competition for water and nutrients. Long-term average monthly (18 years) rainfall data (Figure 1) from the WRF records were used to derive monthly water treatments. Water addition treatments were as follows (Moyo et al. 2015b):

- No water addition $\left(\mathrm{W}_{0}\right)$ - no water additions throughout the study.

- Low $\left(\mathrm{W}_{+}\right)$- trees were supplemented with an amount of water 0.5 times the long-term mean rainfall for that month.

- High $\left(\mathrm{W}_{++}\right)$- trees were supplemented with the long-term mean rainfall for that month (Moyo et al. 2015b).

This monthly amount of rainfall was then divided by four to obtain weekly amounts for supplementing trees for a period of about 18 months beginning in September 2010. Water was applied next to the base of each stump using a watering can (Moyo et al. 2015b).

For the experimental plots that had nutrient additions, nitrogen $(\mathrm{N})$ and phosphorus $(\mathrm{P})$ were supplied using a commercial fertiliser in the form of ammonium phosphate, with a total of $80 \mathrm{~kg} \mathrm{~N} \mathrm{ha}^{-1}$ for the high-fertiliser addition 

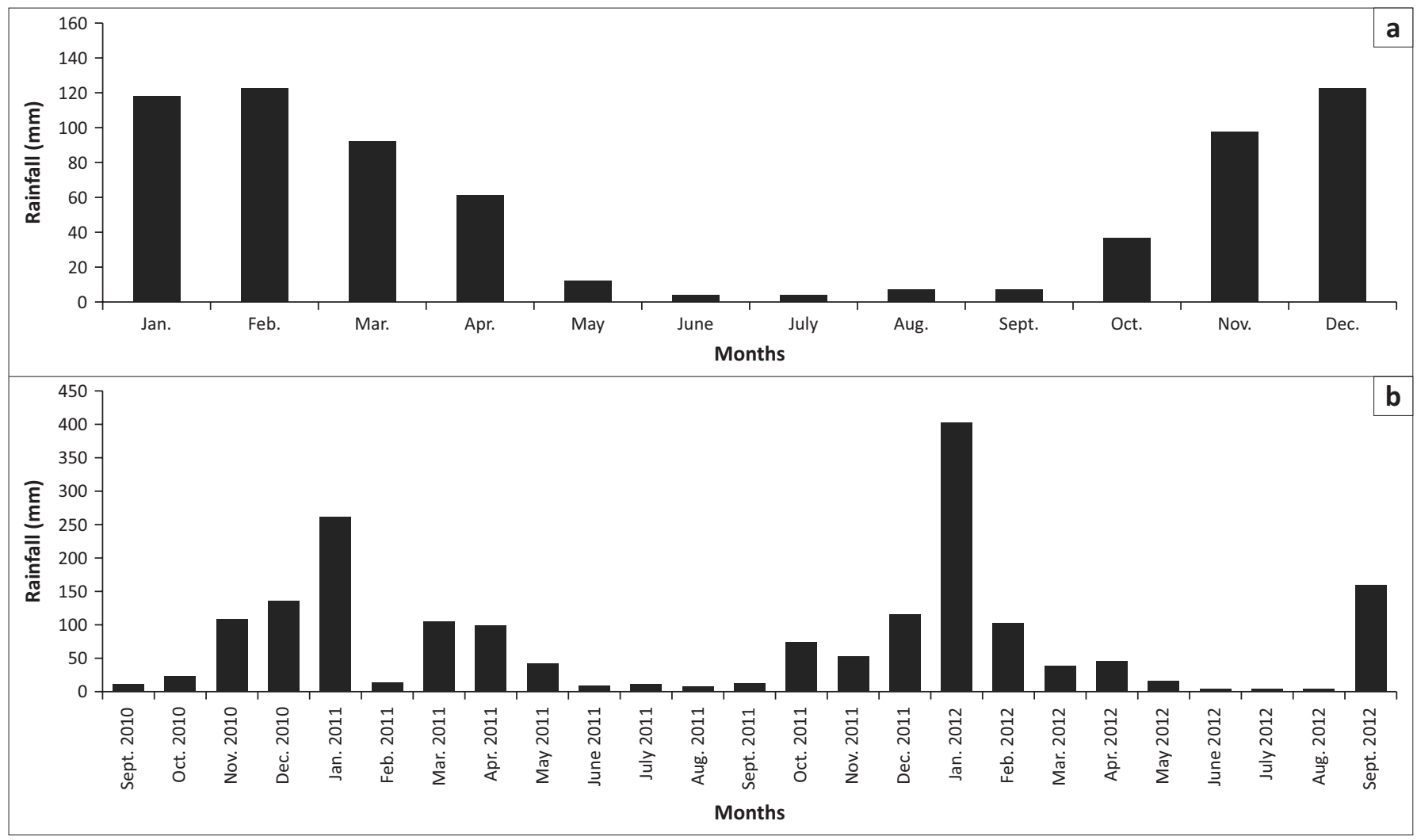

Source: Data courtesy Dr Wayne Twine

FIGURE 1: (a) Long-term mean monthly rainfall distribution (1992-2010) for the Wits Rural Facility and (b) cumulative monthly rainfall data for the duration of the study period (September 2010 - September 2012). January 2012 received exceptionally high amounts of rainfall compared to other January figures for the past 18 years.

treatment and $40 \mathrm{~kg} \mathrm{~N} \mathrm{ha}^{-1}$ for the low-fertiliser addition treatment. Considering that the amount of fertiliser was added once at the beginning of each of the two growing seasons during the study (therefore, twice during the study - in October 2010 and October 2011), this amount (160 kg N ha-1 in total was added) was regarded as a high rate of N application in several studies (Le Roux \& Mentis 1986; Mbatha \& Ward 2010; Tilman 1987) (Moyo et al. 2015b). Fertiliser was added after the first rains fell in October 2010 and also in October 2011. Fertiliser application was done in split applications compared to a single application to avoid, over the course of the wet season, possible leaching of fertiliser through rainfall and added water if applied all at once. A commercial dry fertiliser blended as 4:3:4:1 (N, P, K, and $\mathrm{Zn}$ ) and mixed according to $120 \mathrm{~g} / \mathrm{kg} \mathrm{N}$ and $90 \mathrm{~g} / \mathrm{kg} \mathrm{P}$ was purchased. Fertiliser additions, calculated according to $\mathrm{N}$ and $\mathrm{P}$ on the commercial fertiliser, were as follows (Figure 2):

- No fertiliser addition $\left(\mathrm{N}_{0}\right)$ - no fertiliser additions throughout the study.

- Low $\left(\mathrm{N}_{+}\right)-0.13 \mathrm{~g}$ of $\mathrm{N}$ and $0.1 \mathrm{~g}$ of $\mathrm{P}$ per tree.

- High $\left(\mathrm{N}_{++}\right)-0.27 \mathrm{~g}$ of $\mathrm{N}$ and $0.2 \mathrm{~g}$ of P per tree (Moyo et al. 2015).

The dry fertiliser was applied by coring a hole next to the base of the stump with a diameter of $3 \mathrm{~cm}$ and a depth of about $10 \mathrm{~cm}$ and depositing the fertiliser into the hole. The assumption was that all the fertiliser added using this method was utilised exclusively by the fine tree roots with loss, if any, of approximately the same for the treatments that received fertiliser addition (Moyo et al. 2015b).

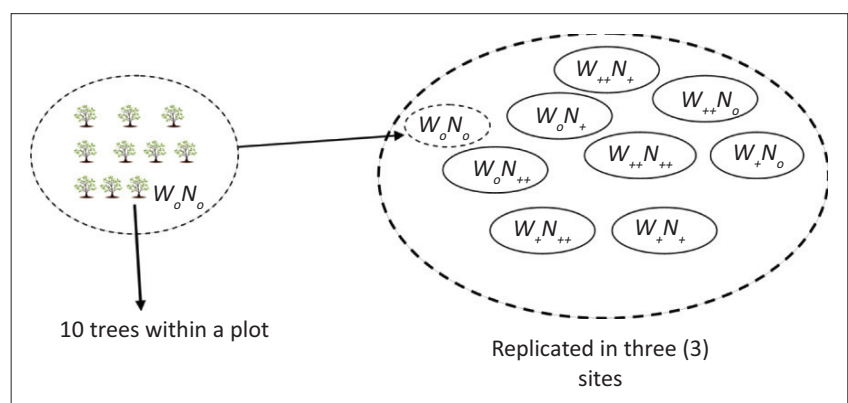

$\mathrm{W}$, water treatment; $\mathrm{N}$, nutrient addition.

FIGURE 2: Factorial experiment designed to investigate the influence of water and nutrient additions on the coppice response of harvested trees.

A combination of the treatments, for example, $\mathrm{W}_{++} \mathrm{N}_{0}$ would mean the treatment is high water addition $\left(\mathrm{W}_{++}^{++}\right)$and no nutrient addition $\left(\mathrm{N}_{0}\right)$.

\section{Morphological measurements}

From each resprouting stump, the following variables were measured per stump on a monthly basis: (1) total number of shoots, (2) resprout shoot diameter (measured above the resprouting zone) and (3) resprout shoot length. For (2) and (3), the leader shoot showing the greatest length was selected and marked using strings.

Shoot production was calculated as the number of shoots produced per unit area of stump basal area. The tree's original stump diameter was measured at the beginning of the experiment and used together with resprout shoot diameter 
to calculate the resprout shoot diameter as a ratio of the original tree's stump diameter. This was termed the resprout ratio.

\section{Total non-structural carbohydrate sampling and determination}

To obtain an indication of TNC dynamics in T. sericea and also to understand how adding water and nutrients affected TNC levels, all trees exposed to treatments as illustrated in Figure 2 were sampled for stem TNC levels twice during the course of the study:

- after a year of treatment application (30 September 2011)

- after 18 months of treatment application, that is, at the end of the wet season (30 April 2012).

Three trees per treatment were sampled using an increment borer (4.3 mm diameter) to extract two 3-cm-long wood cores from the stumps. Before storing the cores in airtight plastic bottles, the outer tree bark was immediately removed from cores after sampling. Core samples were then bottled and placed inside a freezer. Drying of samples was done at $65^{\circ} \mathrm{C}$ for 2 days (assumed dry) and samples were ground using a coffee grinder before finer grinding through a $40-\mu \mathrm{m}$ mesh Wiley mill screen, at the University of Florida, USA (Moyo, Scholes \& Twine 2015a). A composite sample for each treatment was obtained after grinding. The TNC was determined on a dry weight basis using the anthrone method described by Edwards, Downie \& Clingeleffer (2011). The TNC values reported here are the sum of the soluble (glucose and sucrose) and insoluble (starch) fractions (Moyo et al. 2015a).

For comparison, cores from three non-harvested and unsupplemented trees, about $20 \mathrm{~m}$ from the experimental sites, with the same diameter (measured $25 \mathrm{~cm}$ above ground) were sampled for TNC analysis.

\section{Confounding effects}

Because of the presence of antelopes at the study site, the possibility of browsing after tree cutting was very high. The proportion of shoots that were browsed was estimated by counting the total number of shoots resprouting per stump, at the time of recording morphological changes, together with the total number of shoots browsed. The browse proportion was then calculated as the number of browsed shoots relative to the total number of shoots resprouting per stump, and expressed as a percentage. The browse proportion was compared across all the treatments for the duration of the study.

\section{Analyses}

The data were partitioned into two 12-month time intervals to test for the effects of water and nutrient additions on cut trees using linear mixed models implemented in Statistical Analysis Software (SAS) with proc generalised linear model. The September 2010 to September 2011 interval represented the end of the initial 12 months while the September 2011 to
September 2012 interval represented the second 12-month period. Prior to analysis, the total number of shoots, shoot diameter and length data were log-transformed because data were not normally distributed. For the number of shoots, a generalised linear mixed model was fitted using an underlying Poisson distribution with a logit link, which included the fixed effects of treatment. In addition, random effects in terms of site and tree within site were included in the model. All models were fitted using the procedure GLIMMIX as implemented in SAS v. 9.2 (SAS Institute, Cary, NC, USA) (Moyo et al. 2015a).

Significance of fixed effect terms were evaluated with an approximated F-test, with mean comparisons between treatment regimens obtained using least square means with Dunnett's T3. The simple means comparison (unprotected) was used to obtain the level of significance for the total number of shoots. The effects of water and nutrient addition on coppice response (shoot diameter and length) and TNCs were analysed using analysis of variance, and Dunnett's T3 test was used for mean comparison at $p<0.05$ (Moyo et al. 2015a).

\section{Results \\ Effects of water and nutrient additions on coppice response}

Twelve months after trees were cut (September 2011), in the no-water addition treatment $\left(\mathrm{W}_{0}\right)$, shoot production was significantly higher when water was interacting with high nutrient addition $\left(\mathrm{W}_{0} \mathrm{~N}_{++}\right)$than the other nutrient addition treatments. Shoot production was lowest when water was interacting with high nutrient addition, in the low-water addition treatment $\left(\mathrm{W}_{+} \mathrm{N}_{++}\right)$(Figure 3a). There were no significant differences in shoot production in the $W_{++}$ treatment interacting with nutrient treatments in September 2011. The second year after cutting (September 2012), there were no significant differences in shoot production in all water treatment levels interacting with nutrient addition treatments. Between the sampling dates, shoot production reduced markedly across all treatments (Figure 3a).

A year after trees were cut and under $\mathrm{W}_{0}, \mathrm{~W}_{0} \mathrm{~N}_{0}$ recorded the lowest shoot diameter compared to $\mathrm{W}_{0} \mathrm{~N}_{+}$and $\mathrm{W}_{0} \mathrm{~N}_{++}$ (Figure $3 b$ ). For the $W_{+}$treatment, shoot diameter was significantly higher under the $\mathrm{W}_{+} \mathrm{N}_{++}$, compared with $\mathrm{W}_{+} \mathrm{N}_{0}$ and $W_{+} N_{+}$. For the $W_{++}$treatment, significantly higher shoot diameter was only noted when water was interacting with lower nutrient addition $\left(\mathrm{W}_{++} \mathrm{N}_{+}\right)$compared to $\mathrm{W}_{++} \mathrm{N}_{0}$, and not when compared with $\mathrm{W}_{++} \mathrm{N}_{++}$. The second year after cutting, there were no significant differences in shoot diameter in the $W_{0}$ and $W_{++}$treatments interacting with nutrient addition treatments, while in the $W_{+}$treatment, $\mathrm{W}_{+} \mathrm{N}_{+}$and $\mathrm{W}_{+} \mathrm{N}_{++}$recorded significantly higher shoot diameter than $\mathrm{W}_{+} \mathrm{N}_{0}$ (Figure $3 b$ ).

A year after cutting, under $W_{0}$, shoot length was highest under no nutrient addition $\left(\mathrm{W}_{0} \mathrm{~N}_{0}\right)$; in both the $\mathrm{W}_{+}$and $\mathrm{W}_{++}$ 

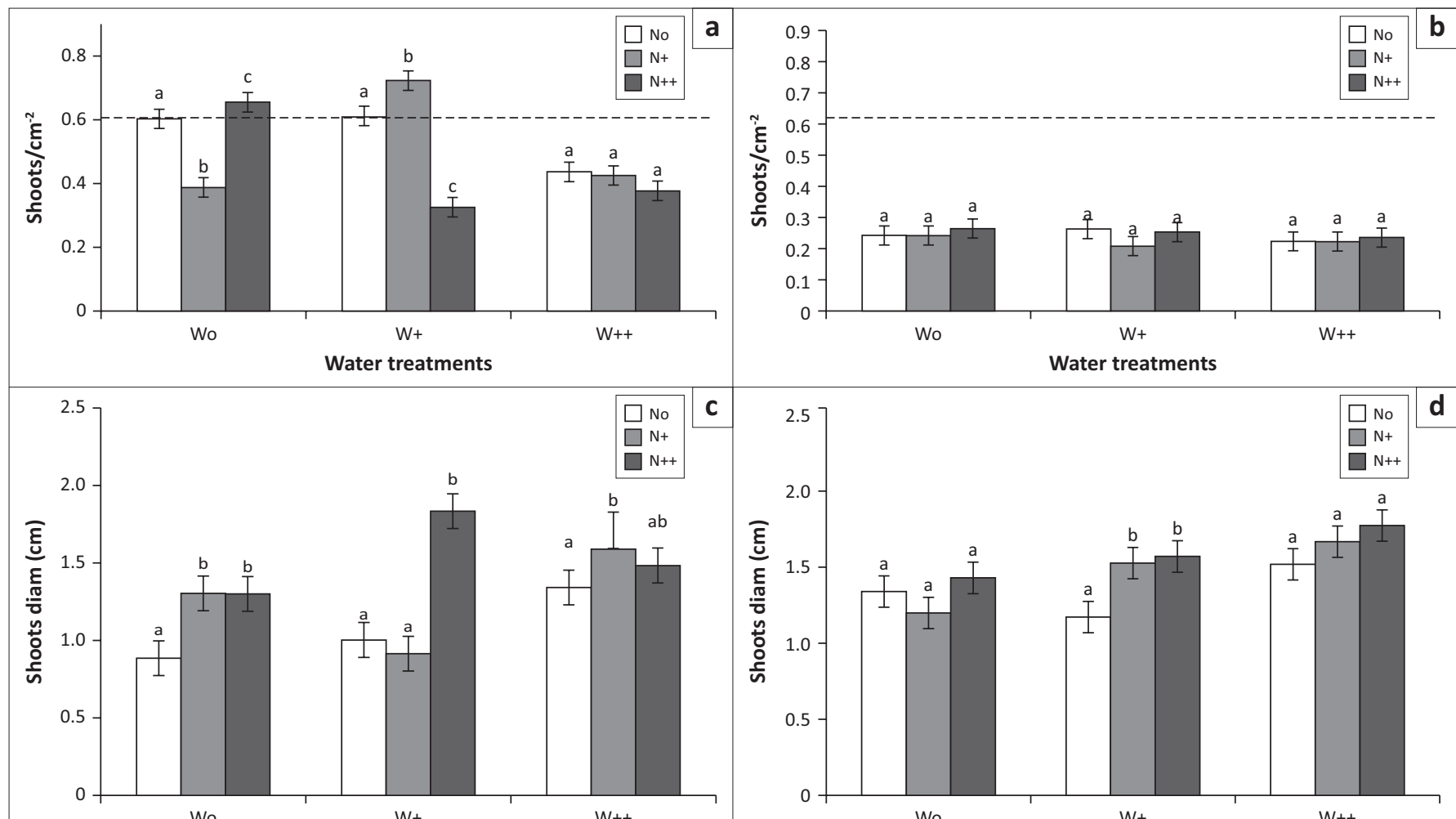

Water treatments

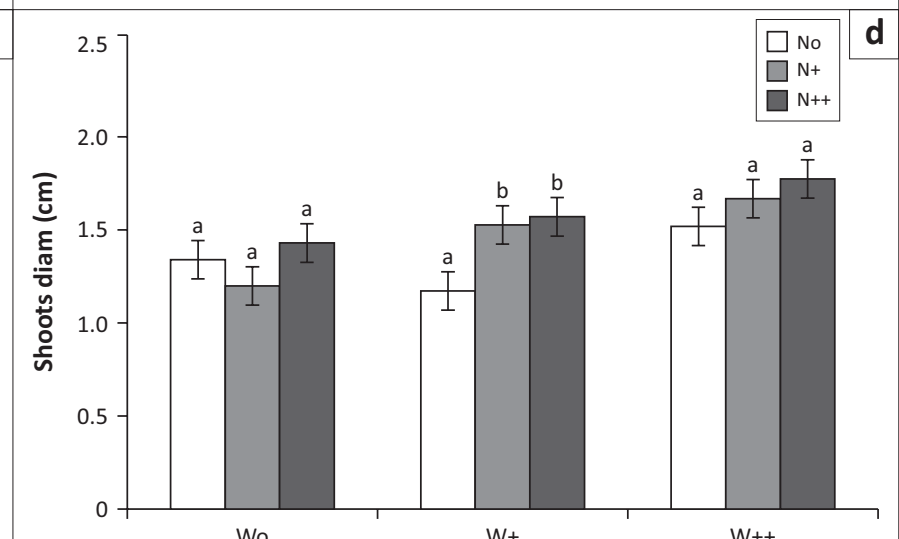

Water treatments

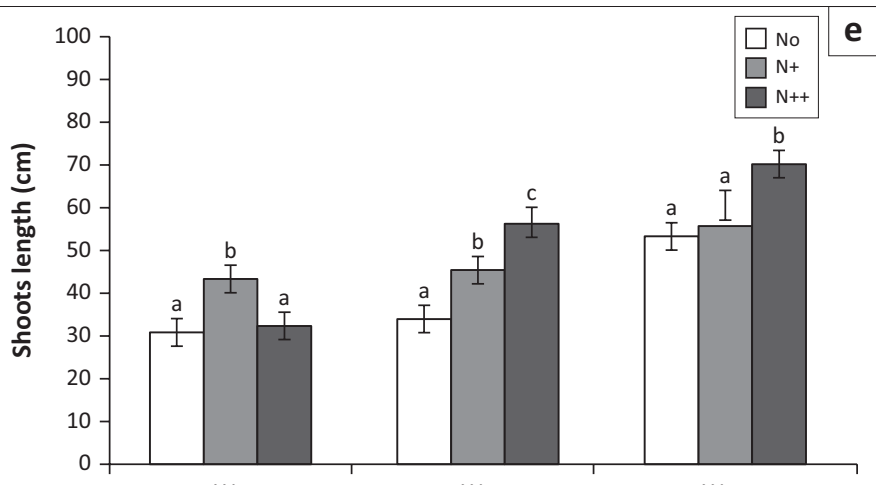

Wo

$\mathrm{W}+$

W++

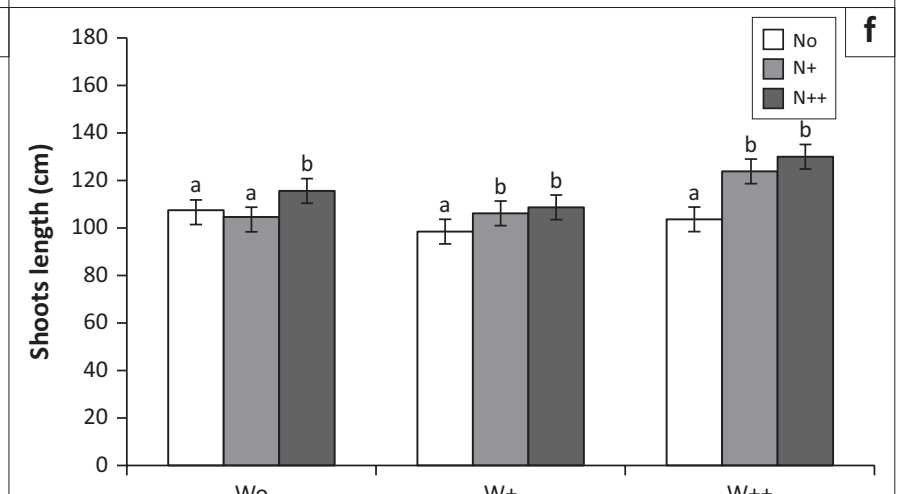

Wo

Water treatments

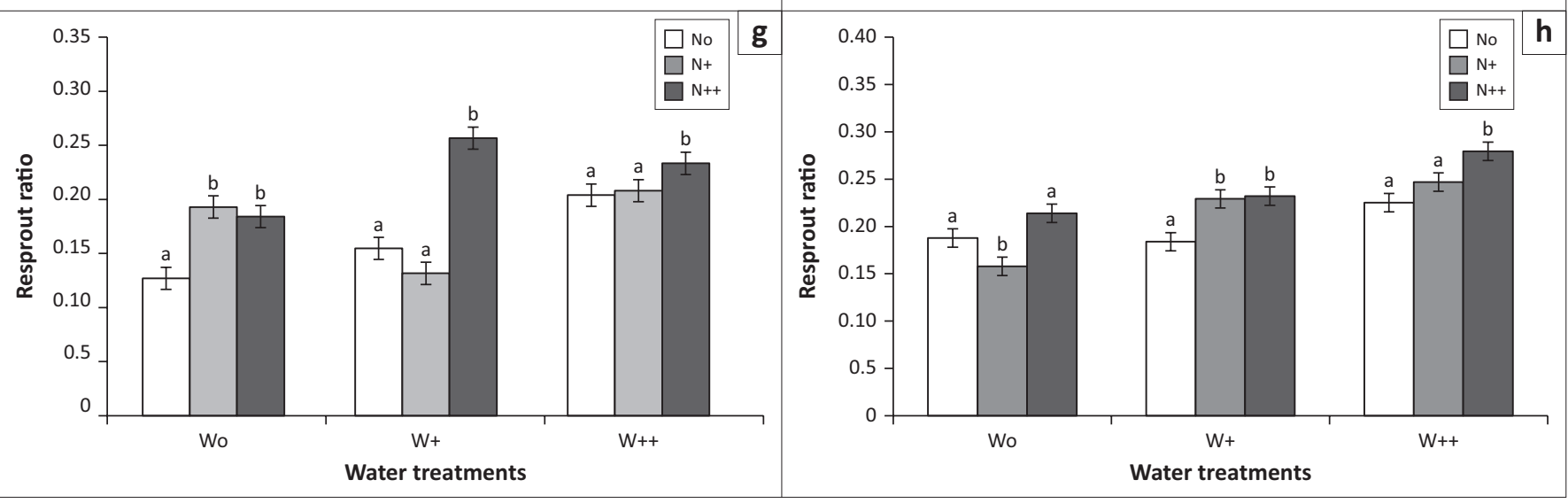

The small letters compare treatment effects across September 2011 while the block letters compare effects across September 2012.

The asterisks indicate treatment differences between the two time points (September 2011 and September 2012).

The means are represented with standard error bars.

( $a$ and $b$ ), The dashed line indicates the drop in shoot production across treatments and between the two time points (September 2011 and September 2012).

(a, c, e, g), September 2011; (b, d, f, h), September 2012

$\mathrm{W}$, water treatment; $\mathrm{N}$, nutrient addition.

FIGURE 3: Effects of water and nutrient addition on ( $\mathrm{a}$ and $\mathrm{b}$ ) shoot production (calculated as number of shoots per unit area of original stump circumference $\mathrm{cm}{ }^{2}$ ), (c and d) shoot diameter, (e and f) shoot length and ( $g$ and $h$ ) resprout ratio (calculated as the ratio of the tree's original stump diameter to that of the leader shoot resprout diameter) between September 2011 and September 2012. 
treatments, shoot length was lowest at the high-nutrient addition level $\left(\mathrm{W}_{+} \mathrm{N}_{++}\right.$and $\left.\mathrm{W}_{++} \mathrm{N}_{++}\right)$. The second year after cutting and under $W_{0^{\prime}}$ shoot length was highest under high nutrient addition $\left(\mathrm{W}_{0} \mathrm{~N}_{++}\right)$, while under $\mathrm{W}_{+}$and $\mathrm{W}_{++}$, shoot length was lowest under no nutrient additions $\left(\mathrm{W}_{+} \mathrm{N}_{0}\right.$ and $\mathrm{W}_{++} \mathrm{N}_{0}$ ) (Figure 3c).

A year after cutting, resprout ratio was significantly lowest for $\mathrm{W}_{0} \mathrm{~N}_{0}$ and highest under $\mathrm{W}_{0} \mathrm{~N}_{++}$and $\mathrm{W}_{++} \mathrm{N}_{++}$for the respective water treatments. For the $W_{0}$ treatment in September 2012, resprout ratio was lowest in $\mathrm{W}_{0} \mathrm{~N}_{+}$, while highest for the $\mathrm{W}_{++} \mathrm{N}_{++}$under the $\mathrm{W}_{++}$(Figure 3d).

\section{Interactive effects of water and nutrient additions on coppice response}

A year after cutting, shoot production was highest when water and nutrient additions were low $\left(\mathrm{W}_{+} \mathrm{N}_{+}\right)$, with no significant differences observed 2 years after the trees were cut (Figure 4a). In September 2011, shoot diameter was significantly highest under the $\mathrm{W}_{+} \mathrm{N}_{++}$, with $\mathrm{W}_{+} \mathrm{N}_{0}$ recording the lowest shoot diameter in September 2012 (Figure 4b). In September 2011, shoot length was significantly higher under the $\mathrm{W}_{++} \mathrm{N}_{++}$, while in September 2012, $\mathrm{W}_{++} \mathrm{N}_{++}$and $\mathrm{W}_{++} \mathrm{N}_{+}$ recorded the highest shoot length (Figure 4c). The resprout ratio was significantly highest for the $\mathrm{W}_{++} \mathrm{N}_{++}$for both the sampling dates, that is, September 2011 and 2012 (Figure 4d).

\section{Effect of water and nutrient additions on stem total non-structural carbohydrate levels}

Supplementing cut trees with water and nutrients had no significant effect on stem TNC concentration for both sampling dates (September 2011 and April 2012) (Table 1). Uncut trees recorded significantly higher TNC levels compared to unsupplemented trees $\left(\mathrm{W}_{0} \mathrm{~N}_{0}\right)$ in September 2011.

\section{Confounding effects: Browsing}

Browsing (percent of shoots browsed per stump) on resprouting trees was widespread in both growing seasons during the study, although it was lower in the second

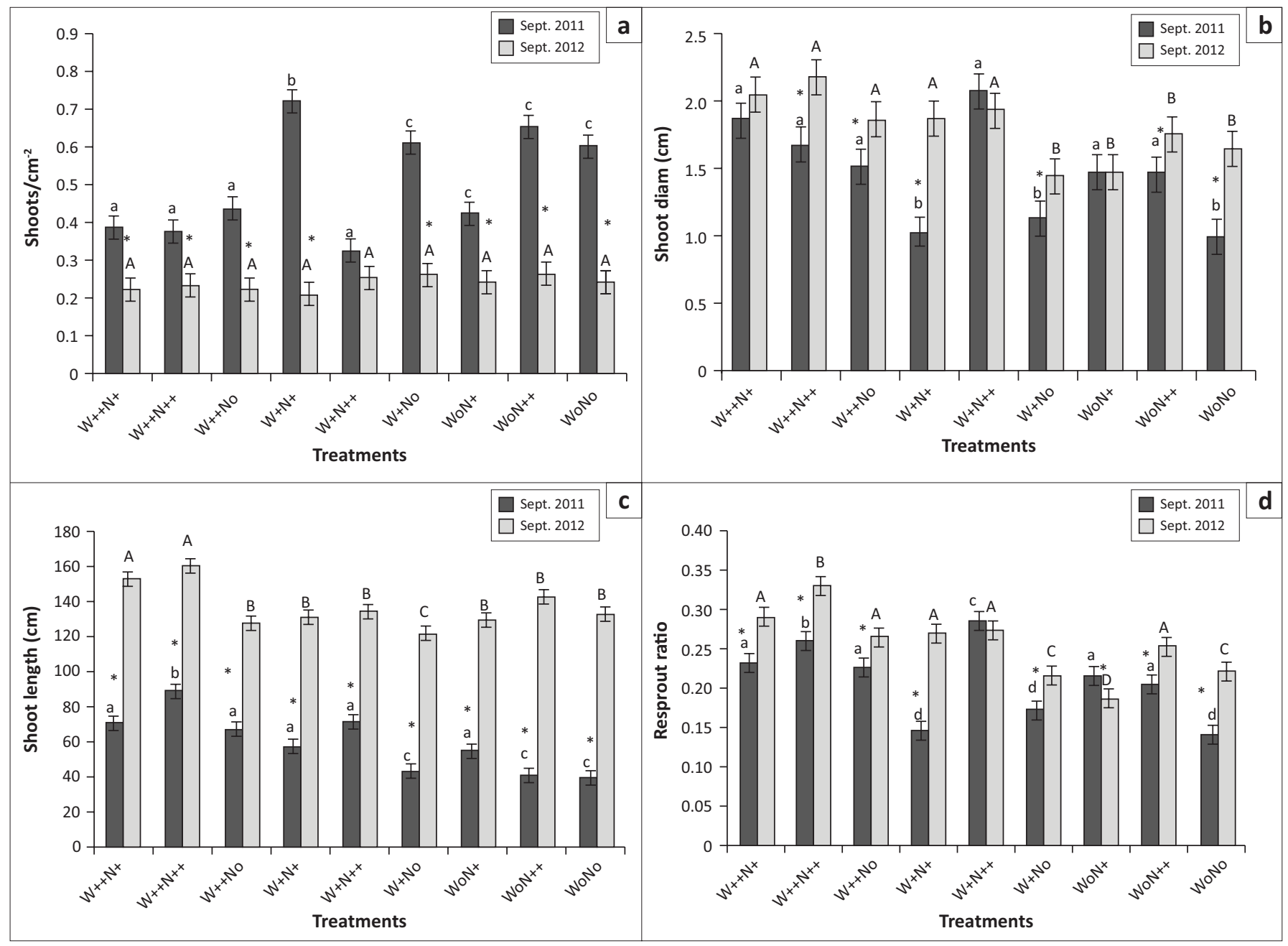

The small letters compare treatment effects across September 2011 while the block letters compare effects across September 2012.

The asterisks indicate treatment differences between the two time points (September 2011 and September 2012).

The means are represented with standard error bars.

$\mathrm{W}$, water treatment; $\mathrm{N}$, nutrient addition.

FIGURE 4: Effects of water and nutrient interaction on (a) shoot production (calculated as the number of shoots per unit area of original stump circumference $\mathrm{cm}^{2}$ ), (b) shoot diameter, (c) shoot length and (d) resprout ratio (calculated as the ratio of the tree's original stump diameter to that of the leader shoot resprout diameter) between September 2011 and September 2012. 
TABLE 1: Differences in total non-structural carbohydrate ( $\mathrm{mg} \mathrm{g}^{-1} \mathrm{DW}$ ) levels between September 2011 and April 2012 as a function of water and nutrient additions.

\begin{tabular}{lll}
\hline Treatment & September 2011 & April 2012 \\
\hline $\mathrm{W}_{0} \mathrm{~N}_{0}$ & $52.37^{\mathrm{a}}(10.8)$ & $38.01^{\mathrm{a}}(11.9)$ \\
$\mathrm{W}_{0} \mathrm{~N}_{++}$ & $51.96^{\mathrm{a}}(13.5)$ & $24.79^{\mathrm{a}}(10.7)$ \\
$\mathrm{W}_{0} \mathrm{~N}_{+}$ & $60.71^{\mathrm{ab}}(16.2)$ & $34.44^{\mathrm{a}}(12.5)$ \\
$\mathrm{W}_{++} \mathrm{N}_{0}$ & $68.62^{\mathrm{ab}}(13.7)$ & $38.96^{\mathrm{a}}(7.8)$ \\
$\mathrm{W}_{++} \mathrm{N}_{++}$ & $65.00^{\mathrm{ab}}(13.8)$ & $46.54^{\mathrm{a}}(17.4)$ \\
$\mathrm{W}_{++} \mathrm{N}_{+}$ & $65.77^{\mathrm{ab}}(39.2)$ & $29.2^{\mathrm{a}}(17.2)$ \\
$\mathrm{W}_{+} \mathrm{N}_{0}$ & $63.80^{\mathrm{ab}}(19.3)$ & $30.88^{\mathrm{a}}(21.8)$ \\
$\mathrm{W}_{+} \mathrm{N}_{++}$ & $66.67^{\mathrm{ab}}(10.1)$ & $43.6^{\mathrm{a}}(19.9)$ \\
$\mathrm{W}_{+} \mathrm{N}_{+}$ & $58.16^{\mathrm{ab}}(12.9)$ & $44.88^{\mathrm{a}}(19.6)$ \\
Non-harvested* & $74.48^{\mathrm{b}}(24.3)$ & $43.09^{\mathrm{a}}(14.4)$ \\
\hline
\end{tabular}

Sample means are represented with standard deviations.

Letters are for treatment comparisons within each time-point. Different letters indicate significant differences within one time point

$\mathrm{W}$, water treatment; $\mathrm{N}$, nutrient addition.

*, Non-harvested refers to trees that were not cut and not supplemented with either water or nutrients at the time of sampling.

compared to the first. There were no significant differences $(F=1.57, p=0.167)$ in browsing proportion across all treatments during the study.

\section{Discussion}

Water and nutrient addition had initial significant effects on shoot production, while, as hypothesised, the addition of water and nutrients resulted in significant increases in resprout shoot diameter and shoot length. Contrary to the hypothesis, adding water and nutrients did not result in significant increases in stem TNC levels at both sampling dates, September 2011 and April 2012.

\section{Effects of water and nutrients on coppice response of cut trees}

High water and nutrient addition had a significant effect on shoot production after 12 (but not after 24) months. The differences in tree responses can possibly be attributed to the higher amount of rainfall received in the 2012 rainfall season compared to the 2011 season, contributing to treatment effects being non-measurable in 2012. Alternatively, this pattern could also be interpreted as generally the speeding up of the resprouting process because resprouting trees start off with many small shoots and, over time, tend to invest in fewer and larger shoots. Therefore, the effect of water and nutrients could have been to speed up the rate at which this shift in allocation happens.

Similar nutrient addition effects have been reported when there was an increase in the above-ground shoot production in Pinus taeda L., Pinus elliottii and Liquidambar styraciflua L. (Albaugh et al. 2004; Cobb et al. 2008), in Populus deltoids Bartr. and Planatus occidentalis L. (Coyle \& Coleman 2005), and shoot biomass and growth in Quercus macrocarpa Michx. and northern pin oak Quercus ellipsoidalis E. J. Hill (Davis et al. 1999).

Shoot length and diameter for trees supplemented with water and nutrients were significantly higher in the $\mathrm{W}_{++} \mathrm{N}_{++}$ treatment between September 2011 and September 2012.
Under high soil moisture conditions, there is a general increase in sprouting vigour leading to the transfer and supply of growth promoters such as auxins, cytokinins and gibberellins (Ferm \& Kauppi 1990). This is not the case when there is very low soil moisture (Liu \& Dickmann 1996). Consequently, adding water for this study may have led to an overall increase in cell division and resprouting shoots exhibit stronger apical dominance, resulting in higher average shoot diameters and lengths compared to $\mathrm{W}_{0} \mathrm{~N}_{0}$ trees.

It has been proposed that fertiliser addition increases foliar $\mathrm{N}$ concentrations as well as chlorophyll levels, leading to an increase in photosynthetic efficiency (Scott et al. 2004). In this study, nutrient addition possibly resulted in increased leaf area (Ewers et al. 1999), thus increasing the surface area for elevated photosynthetic activity. This may have contributed to an increase in shoot elongation and shoot thickness. Results from this study are similar to those obtained by Osman and AboHassan (2010), when shoot production and resprout shoot length increased after the addition of $\mathrm{N}$ and addition of P to Rhizophora mangle L. (Lovelock et al. 2004). In addition, current findings are also supported by results from the addition of $\mathrm{N}$ to thinned $P$. taeda, which increased resprout diameter and length (Sayer et al. 2004).

In line with this study's findings, shoot diameter and height were higher in Pinus ponderosa Dougl. ex P. Laws. and C. Laws, which received $\mathrm{N}$ addition compared to trees which received no additions (Tingey et al. 1996), with both height and diameter growth in fertilised stands doubling in comparison to the non-fertilised stands in Norway spruce (Picea abies [L.] Karst.) (Bergh et al. 1999).

An overall reduction in the number of shoots for all treatments at the beginning of the wet season in September 2012 implies that there was self-thinning. Between September 2011 and September 2012, there was over 50\% reduction in the number of shoots in all treatments. While self-thinning could be viewed as a way of reducing high respiration demands associated with high leaf material, this growth pattern was observed even on supplemented trees. Findings from this study could possibly mean that resource availability does not necessarily control self-thinning, that is, self-thinning may, in fact, be controlled within the trees and not by environmental factors.

\section{Effect of water and nutrients on stem total non-structural carbohydrate levels}

Adding water and nutrients had no significant effect on stem TNC levels at both time points. This was surprising given that an increase in soil moisture and nutrient levels through resource additions on the same trees extended leaf survival early into the dry season (Moyo et al. 2015), thereby possibly extending the period of photosynthesis for trees supplemented. Such an extension of the period of photosynthesis maintained greater leaf area, possibly leading 
to higher carbon assimilation in supplemented trees. This was in comparison to unsupplemented trees, which had leaf survival that only lasted to the end of the growing season, thereby photosynthesising for a shorter period. Given this, the expectation was that these phenological shifts in the dry season (September 2011) extended the photosynthetically active period so that supplemented trees rely less on stored reserves for regrowth compared to unsupplemented trees.

Because TNC concentrations in tree tissues are considered a measure of carbon storage or a demand for growth (Druege et al. 2000; Kabeya \& Sakai 2005; Sakai \& Sakai 1998), the lack of significant effects the addition of water and nutrients may indicate that the carbon demand in resprouting trees, even for supplemented trees which had a longer period to photosynthesise, was exceeding the supply from photosynthesis alone, as stored TNC were mobilised for growth. Resprouting trees appear to continuously draw from stored reserves.

Findings from this study are different to work on Q. crispula Blume, where root TNC levels were higher after resource addition (Kabeya \& Sakai 2005). Similar to findings from this study, other studies also found that $\mathrm{N}$ additions had no effect on carbohydrate reserves in beech (Fugus sylvatica L.) (Pahlsson 1992), while it had little effect on starch levels for Chrysanthemum cuttings (Druege et al. 2000).

In protected areas such as game reserves and conservation areas, a fire can open up patches of land (Ward 2005), exposing seeds and seedlings to resources such as light and nutrients. Such disturbances, coupled with the fluctuation in rainfall distribution in semi-arid areas (Scholes \& Archer 1997), create bush encroachment patches absent when no fire events or disturbances occur (Ward 2005). In agreeing with this study's findings, this is true when considering the quick recovery of shoot length and diameter in T. sericea after a cutting event. This quick recovery may eventually result in this species encroaching large areas of land, thus reducing the biodiversity and species distribution of the herbaceous vegetation.

Browsing proportion was the same across all treatments, implying that while browsing may have influenced shoot length and, possibly, the number of shoots produced as well as total biomass produced, the influence was evenly spread across all the treatments. Therefore, browsing did not unduly influence the relative differences in the variables measured between treatments.

Water and nutrients were supplemented through addition immediately adjacent to the tree stump. Water addition may have facilitated nutrient uptake, and we assumed that this type of water and nutrient addition enhanced the tree's ability of fine roots to absorb most of the resources added. The mean annual rainfall in the study area $(650 \mathrm{~mm}$ per annum) lies between the upper and lower limits of the study species range. Considering that $T$. sericea adapts well to droughts (Griffiths 1959), the rainfall in the area is intermediate when compared to the lower limit of the species range. For a tree species adapted to growing in a resourcepoor environment, this may mean that the weaker effects of water addition in the second season may have been a result of the study species' allocation of resources towards storage, instead of growth, as suggested by Witkowski, Mitchell and Stock (1990). Such allocation may help explain the low effectiveness of high water addition on coppice regrowth during the second season of growth.

\section{Conclusion}

This study demonstrated that resprouting is water and nutrient limited in cut trees and that resource addition does not replenish the stem carbon storage. The results suggest that water is limiting for resprout shoot diameter and length, but not for shoot production and stem storage carbohydrates. Results from this study thus support the hypothesis that supplementing cut trees with water and nutrients increases coppice growth, but this effect holds primarily only for the first growing season after cutting, with the effect declining over time. Results from a follow-up study also suggest that even though a tree supplemented with water and nutrients may end up photosynthesising for a longer period compared to an unsupplemented tree, this does not necessarily change the tree's reliance on stored carbon reserves for regrowth early in the growing season.

Total number of shoots produced displays clear self-thinning and it is interesting to note that water and nutrient additions do not impact this self-thinning. This suggests that selfthinning may be light related and is not positively related with resource availability. Future research could focus on how adding water and nutrients changes the balance of TNC in roots and stems, and not only the stem TNC as covered in this current study. Cutting of trees at shorter intervals, for example, logging and short coppice rotation can be done in environments that have higher water and nutrient levels, because a quicker recovery of lost biomass is expected in resource-rich environments compared to resource-poor environments (Moyo et al. 2015). In an ecosystem where competition for food is high and resources for plant growth are limited, new leaves can be a major source of food at a time when most herbivores struggle to fulfil their nutritional needs, especially at the end of the dry season. Therefore, this would ensure that herbivores are assured of a food source, because cattle have been shown to browse more than graze during the dry season (Katjiua \& Ward 2006). In order to reduce the possibility of this study species encroaching large areas, disturbances such as hot fires, which burn and open up large patches, should be controlled. This is because hot fires open up large patches, leading to vigorous resprouting of this species, which may threaten biodiversity in the long run.

\section{Acknowledgements}

This research was funded by the Mellon Foundation and the Centre for Tree Health and Biotechnology (FABI, University 
of Pretoria). The assistance of Julia Reiskind, Ed Witkowski, Sally Archibald, Ricardo Holdo, Michelle Mack, Thabo Sibuyi and Frank Nyathi is appreciated. The WRF is appreciated for making the sites available.

\section{Competing interests}

The authors declare that they have no financial or personal relationships which may have inappropriately influenced them in writing this article.

\section{Authors' contributions}

H.M. was responsible for designing the study, field work and data collection including the analysis and writing up of the paper. M.C.S. guided the first author and read drafts of the paper, while W.T. also read and corrected drafts of the paper as well as formulated the study design.

\section{References}

Albaugh, T.J., Lee Allen, A., Dougherty, P.M. \& Johnesen, K.H., 2004, 'Long term growth responses of loblolly pine to optimal nutrient and water resource availability',
Forest Ecology and Management 192, 3-19. http://dx.doi.org/10.1016/j. Forest Ecology and
foreco.2004.01.002

Avohou, T.H., Houehounha, R., Glele-Kakai, R., Assogbadjo, A.E. \& Sinsin, B., 2011 'Firewood yield and profitability of a traditional Daniellia oliveri short-rotation coppice on fallow lands in Benin', Biomass and Bioenergy 35, 562-571. http:// coppice on fallow lands in Benin', Biomass
dx.doi.org/10.1016/j.biombioe.2010.10.030

Bellingham, P.J. \& Sparrow, A.D., 2000, 'Resprouting as a life history strategy in woody plant communities', Oikos 89, 409-416. http://dx.doi.org/10.1034/j.1600-0706. 2000.890224.x

Bergh, J., Lindera, S., Lundmark, T. \& Elfving, B., 1999, 'The effect of water and nutrient availability on the productivity of Norway spruce in northern and southern Sweden', Forest Ecology and Management 119, 51-62.

Bond, W.J. \& Midgley, J.J., 2001, 'Ecology of sprouting in woody plants: The persistence niche', Trends in Ecology \& Evolution 16(1), 45-51. http://dx.doi.org/10.1016/ S0169-5347(00)02033-4

Bowen, B.J. \& Pate, J.S., 1992, 'The significance of root starch in post-fire shoot recovery of the resprouter Stirlingia latifolial R. Br. (Proteaceae)', Annals of Botany 72, 7-16. http://dx.doi.org/10.1006/anbo.1993.1075

Castell, C. \& Terradas, J., 1994, 'Effects of water and nutrient availability on water relations, gas exchange and growth rate of mature plants and resprouts of Arbutus unedo L.', Annals of Botany 73, 595-602. http://dx.doi.org/10.1006/anbo. 1994.1074

Chapin III, F.S., 1991, 'Integrated responses of plants to stress', Bioscience 41(1), 29-36. http://dx.doi.org/10.2307/1311538

Cheng, L. \& Fuchigami, L.H., 2002, 'Growth of young apple trees in relation to reserve nitrogen and carbohydrates', Tree Physiology 22, 1297-1303. http://dx.doi. org/10.1093/treephys/22.18.1297

Cobb, W.R., Will, R.E., Daniels, R.F. \& Jacobson, M.A., 2008, 'Aboveground biomass and nitrogen in four short-rotation woody crop species growing with different water and nutrient availabilities', Forest Ecology and Management 255, 4032-4039. http://dx.doi.org/10.1016/j.foreco.2008.03.045

Coyle, D.R. \& Coleman, M.D., 2005, 'Forest production responses to irrigation and fertilization are not explained by shifts in allocation', Forest Ecology and Management 208, 137-152. http://dx.doi.org/10.1016/j.foreco.2004.11.022

Cruz, A., Perez, B., Quintana, J.R. \& Moreno, J.M., 2002, 'Resprouting in the Mediterranean-type shrub Erica australis afffected by soil resource availability', Journal of Vegetation Science 13, 641-650. http://dx.doi.org/10.1658/1100 9233(2002)013[0641:ritmse]2.0.co;2

Davis, M., Wrage, K.J., Reich, P.B., Tjoelker, M.G., Schaeffer, T. \& Muermann, C., 1999, 'Survival, growth, and photosynthesis of tree seedlings competing with herbaceous vegetation along a water-light-nitrogen gradient', Plant Ecology 145 341-350. http://dx.doi.org/10.1023/A:1009802211896

Dickmann, D.I., Nguyen, P.V. \& Pregitzer, K.S., 1996, 'Effects of irrigation and coppicing on above-ground growth, physiology, and fine-root dynamics of two field-grown hybrid poplar clones', Forest Ecology and Management 80, 163-174. http://dx. doi.org/10.1016/0378-1127(95)03611-3

Druege, U., Zerche, S., Kadner, R. \& Ernst, M., 2000, 'Relation between nitrogen status, carbohydrate distribution and subsequent rooting of Chrysanthemum cuttings as affected by pre-harvest nitrogen supply and cold-storage', Annals of Botany 85 687-701. http://dx.doi.org/10.1006/anbo.2000.1132

Edwards, E.J., Downie, A.F. \& Clingeleffer, P.R., 2011, 'A simple microplate assay to quantify non-structural carbohydrates of Grapevine tissues', American Journal of Ecology and Viticulture 62(1), 133-137. http://dx.doi.org/10.5344/ajev. 2010.10051
El Omari, B., Aranda, X., Verdaguer, D., Pascual, G. \& Fleck, I., 2003, 'Resource remobilization in Quercus ilex L. resprouts', Plant and Soil 252, 349-357. http:// rx.doi.org/10.1023/A:1024792206369

Ewers, B.E., Oren, R., Albaugh, T.J. \& Dougherty, P.M., 1999, 'Carry-over effects of water and nutrient supply on water use of Pinus taeda', Ecological Applications 9(2), 513-525. http://dx.doi.org/10.1890/1051-0761(1999)009[0513:COEOWA] 2.0.CO;2

Ferm, A. \& Kauppi, A., 1990, 'Coppicing as a means for increasing hardwood biomass production', Biomass 22(1-4), 107-121. http://dx.doi.org/10.1016/0144-4565 (90) $90010-\mathrm{H}$

Fircks, Y.V. \& Sennerby-Forsse, L., 1998, 'Seasonal fluctuations of starch in root and stem tissues of coppiced Salix viminalis plants grown under two nitrogen regimes', Tree Physiology 18, 243-249. http://dx.doi.org/10.1093/treephys/18.4.243

Griffiths, M.E., 1959, 'A revision of the African Species of Terminalia', Journal of the Linnean Society of London Botany 25, 364. http://dx.doi.org/10.1111/j.1095-8339. 1959.tb00042.x

Hardesty, L.H., 1984, 'The challenge of integrated brush management in semi-arid tropics', Rangelands 6(6), 249-253.

Hoffmann, W.A., Schroeder, W. \& Jackson, R.B., 2002, 'Positive feedbacks of fire, climate, and vegetation and the conversion of tropical savanna', Geophysics Research Letters 29(22), 2052-2056. http://dx.doi.org/10.1029/2002GL015424

Holdo, R.M., Holt, R.D. \& Fryxell, J.M., 2009, 'Grazers, browsers, and fire influence the extent and spatial pattern of tree cover in the Serengeti', Ecological Applications 19(1), 95-109. http://dx.doi.org/10.1890/07-1954.1

Hytonen, J. \& Kaunisto, S., 1999, 'Effect of fertilization on the biomass production of coppiced mixed birch and willow stands on a cut-away peatland', Biomass and Bioenergy 17, 455-469. http://dx.doi.org/10.1016/S0961-9534(99)00061-6

Ibrahima, A., Mapongmetsem, P.M., Bouitang, D. \& Hassana, B., 2007, 'Regeneration of some fuelwood tree species of humid savanna of Adamawa, Cameroon: Effects of season and cutting height', Ghana Journal of Science 47, 45-57.

Kabeya, D. \& Sakai, S., 2005, 'The relative importance of carbohydrate and nitrogen for the resprouting ability of Quercus crispula seedlings', Annals of Botany 96 479-488. http://dx.doi.org/10.1093/aob/mci200

Kabeya, D., Sakai, A., Matsui, K. \& Sakai, S., 2003, 'Resprouting ability of Quercus crispula seedlings depends on the vegetation cover of their microhabitats' Journal of Plant Research 116, 207-216. http://dx.doi.org/10.1007/ s10265-003-0089-3

Kaschula, S., Twine, W. \& Scholes, M., 2005a, 'Coppice harvesting of fuelwood species on a South African common: Utilizing scientific and indigenous knowledge in community based natural resource management', Human Ecology 33, 387-418. http://dx.doi.org/10.1007/s10745-005-4144-7

Kaschula, S.A., Twine, W.C. \& Scholes, M.C., 2005b, 'The effect of catena position and stump characteristics on the coppice response of three savannah fuelwood species', Environmental Conservation 32(1), 76-84.

Katjiua, M.L.J. \& Ward, D., 2006, 'Cattle diet selection during the hot-dry season in a semi-arid region of Namibia', African Journal of Range \& Forage Science 23, 59-67.

Khan, M.L. \& Tripathi, R.S., 1986, 'Tree regeneration in a disturbed sub-tropical wet hill forest of north-east India: Effect of stump diameter and height on sprouting of four tree species', Forest Ecology and Management 17, 199-209. http://dx.doi. org/10.1016/0378-1127(86)90112-X

Kraaij, T. \& Ward, D., 2006, 'Effects of rain, nitrogen, fire and grazing on tree recruitment and early survival in bush-encroached savanna, South Africa', Plant Ecology 186(2), 235-246. http://dx.doi.org/10.1007/s11258-006-9125-4

Laureysens, I., Deraedt, W., Indeherberge, T. \& Ceulemans, R., 2003, 'Population dynamics in a 6 -year old coppice culture of poplar. I. Clonal differences in stool mortality, shoot dynamics and shoot diameter distribution in relation to biomass production', Biomass and Bioenergy 24, 81-95. http://dx.doi. org/10.1016/S0961-9534(02)00105-8

Le Roux, N.P. \& Mentis, M.T., 1986, 'Veld compositional response to fertilization in the tall grassveld of Natal', South African Journal of Plant and Soil 3, 1-10. http:// dx.doi.org/10.1080/02571862.1986.10634177

Liu, Z. \& Dickmann, D.I. 1996, 'Effects of water and nitrogen interaction on net photosynthesis, stomatal conductance, and water-use efficiency in two hybrid
poplar clones', Physilogia Plantarium 97, 507-512. http://dx.doi.org/10.1111/j. poplar clones', Physilogia Plan
1399-3054.1996.tb00510.x

Lovelock, C.E., Feller, I.C., McKee, K.L., Engelbrecht, B.M.J. \& Ball, M.C., 2004, 'The effect of nutrient enrichment on growth, photosynthesis and hydraulic conductance of dwarf mangroves in Panama', Functional Ecology 18, 25-33. conductance of dwarf mangroves in Panama', Functio
http://dx.doi.org/10.1046/j.0269-8463.2004.00805.x

Mbatha, K.R. \& Ward, D., 2010, 'The effects of grazing, fire, nitrogen and water availability on nutritional quality of grass in semi-arid savanna, South Africa', Journal of Arid Environments 74, 1294-1301. http://dx.doi.org/10.1016/j. jaridenv.2010.06.004

Moyo, H.P.M., Scholes, M.C. \& Twine, W.C., 2015a, 'The effects of repeated cutting on coppice response of Terminalia sericea', Trees 29(1), 161-169.

Moyo, H.P.M., Scholes, M.C. \& Twine, W.C., 2015b, 'The effects of water and nutrient addition on the pehnological response of cut Terminalia sericea', South African Journal of Botany 96, 85-90. http://dx.doi.org/10.1016/j.sajb.2014.10.009

Neke, K.S., 2004, The regeneration ecology of savanna woodlands in relation to human utilisation, University of the Witwatersrand, Johannesburg.

Neke, K.S., Owen-Smith, N. \& Witkowski, E.T.F., 2006, 'Comparative resprouting response of Savanna woody plant species following harvesting: The value of persistence', Forest Ecology and Management 232(1-3), 114-123. http://dx.doi. org/10.1016/j.foreco.2006.05.051 
Noumi, Z., Touzard, B., Michalet, R. \& Chaieb, M., 2010, 'The effects of browsing on the structure of Acacia tortilis (Forssk.) Hayne ssp. raddiana (Savi) Brenan along a
gradient of water availability in arid zones of Tunisia', Journal of Arid Environments 74(6), 625-631. http://dx.doi.org/10.1016/j.jaridenv.2009.11.007

Osman, H.E. \& AboHassan, A.A., 2010, 'Effect of NPK fertilization on growth and dry matter accumulation in Mangrove [Avicennia marina (Forssk) vierh] grown in Western Saudi Arabia', Environmental \& Arid Land Agricultural Science 21(2), 57-70. http://dx.doi.org/10.4197/met.21-2.5

Pahlsson, A.B., 1992, 'Influence of nitrogen fertilization on minerals, carbohydrates, amino acids and phenolic compounds in beech (Fugus sylvatica L.) leaves', Tree Physiology 10, 93-100. http://dx.doi.org/10.1093/treephys/10.1.93

Pote, J., Shackleton, C., Cocks, M. \& Lubke, R., 2006, 'Fuelwood harvesting and selection in Valley Thicket, South Africa', Journal of Arid Environments 67(2), 270-287. http://dx.doi.org/10.1016/j.jaridenv.2006.02.011

Rooke, T. \& Bergstrom, R., 2007, 'Growth, chemical responses and herbivory after simulated leaf browsing in Combretum apiculatum', Plant Ecology 189, 201-212. $\mathrm{http}: / / \mathrm{dx}$.doi.org/10.1007/s11258-006-9177-5

Sakai, A. \& Sakai, S., 1998, 'A test for the resource remobilization hypothesis: Tree sprouting using carbohydrates from above-ground parts', Annals of Botany 82 213-216. http://dx.doi.org/10.1006/anbo.1998.0672

Sankaran, M., Ratnam, J. \& Hanan, N., 2008, 'Woody cover in African savannas: The role of resources, fire and herbivory', Global Ecology and Biogeography 17(2), 236-245. http://dx.doi.org/10.1111/j.1466-8238.2007.00360.x

Sayer, S.M.A., Goelz, J.C.G., Chambers, J.L., Tang, Z., Dean, T.J., Haywood, J.D., et al., 2004, 'Long-term trends in loblolly pine productivity and stand characteristics in response to thinning and fertilization in the West Gulf region', Forest Ecology and Management 192, 71-96. http://dx.doi.org/10.1016/j.foreco.2004.01.006

Scholes R.J. \& Archer, S.R., 1997, 'Tree-grass interactions in savannas', Annual Review Ecological Systems 28, 517-544.

Scogings, P.F. \& Mopipi, K., 2008, 'Effects of water, grass and N on responses of Acacia karroo seedlings to early wet season simulated browsing: Leaf $\mathrm{N}$, fibre and tannin concentrations', Journal of Arid Environments 72(9), 1666-1674. http://dx.doi. org/10.1016/j.jaridenv.2008.03.008
Scott, D.A., Burger, J.A., Kaczmarek, D.J. \& Kane, M.B., 2004, 'Growth and nutrition response of young sweetgum plantations to repeated nitrogen fertilization on two site types', Biomass and Bioenergy 27, 313-325. http://dx.doi.org/10.1016/j. site types, Biomass and
biombioe.2004.02.003

Shackleton, C.M., 1997, The prediction of woody plant productivity in the Savanna biome, South Africa, University of the Witwatersrand, Johannesburg.

Shackleton, C.M., 1999, 'Rainfall and topo-edaphic influences on woody community phenology in South African savannas', Global Ecology and Biogeography 8 , 125-136. http://dx.doi.org/10.1046/j.1365-2699.1999.00128.x

Tilman, D., 1987, 'Secondary succession and the pattern of plant dominance along experimental nitrogen gradients', Ecological Monographs 57(3), 189-214. http:// dx.doi.org/10.2307/2937080

Tingey, D.T., Johnson, M.G., Phillips, D.L., Johnson, D.W. \& Ball, T.J., 1996, 'Effects of elevated $\mathrm{CO}_{2}$ and nitrogen on the synchrony of shoot and root growth in ponderosa pine', TreePhysiology 16,905-914. http://dx.doi.org/10.1093/treephys/16.11-12.905

Van Wyk, B. \& Van Wyk, P., 1997, Field guide to trees of Southern Africa, Struik Publishers, Cape Town.

Ward, D., 2005, 'Do we understand the causes of bush encroachment in African savannas?', African Journal of Range \& Forage Science 22(2), 101-105. http:// dx.doi.org/10.2989/10220110509485867

Wendler, R. \& Millard, P., 1996, 'Impacts of water and nitrogen supplies on the physiology, leaf demography and nitrogen dynamics of Betula pendula', Tree Physiology 16, 153-159. http://dx.doi.org/10.1093/treephys/16.1-2.153

Wilson, B., 2002, Population dynamics and the regeneration ecology of the African savanna tree Burkea africana, University of the Witwatersrand, Johannesburg.

Wilson, T.B. \& Witkowski, E.T.F., 1998, 'Water requirements for germination and early seedling establishment in four African savanna woody plant species', Journal of Arid Environments 38, 541-550. http://dx.doi.org/10.1006/jare.1998.0362

Witkowski, E.T.F., Mitchell, D.T. \& Stock, W.D., 1990, 'Response of a Cape fynbos ecosystem to nutrient additions: Shoot growth and nutrient contents of a proteoid (Leucospermum parile) and ericoid (Phylica cephalantha) evergreen shrub', Acto Ecologica 11(3), 311-326. 